\title{
Evaluation of salt stress tolerance of chilli (Capsicum annuum L.) genotypes at seedling stage
}

Niaz Ahmed Wahocho ${ }^{1 *}$, Hamayun Latif ${ }^{1}$, Noor-un-Nisa Memon ${ }^{1}$, Qadir Bux Baloch ${ }^{1}$, Ahmed Naqi Shah ${ }^{2}$, Zulfiquar Ali Abbasi², Abdul Qadir Gola ${ }^{1}$, Safdar Ali Wahocho ${ }^{1}$, Muhammad Iqbal Jakhro ${ }^{3}$ and Javed Ahmed Abro ${ }^{3}$

1. Department of Horticulture, Sindh Agriculture University Tandojam-Pakistan

2. Department of Agronomy, Sindh Agriculture University Tandojam-Pakistan

3. PARC Balochistan Agricultural Research \& Development Center, Quetta-Pakistan

*Corresponding author's email: nawahocho@gmail.com

Citation

Niaz Ahmed Wahocho, Hamayun Latif, Noor-un-Nisa Memon, Qadir Bux Baloch, Ahmed Naqi Shah, Zulfiquar Ali Abbasi, Abdul Qadir Gola, Safdar Ali Wahocho, Muhammad Iqbal Jakhro and Javed Ahmed Abro. Evaluation of salt stress tolerance of chilli (Capsicum annuиm L.) genotypes at seedling stage. Pure and Applied Biology. Vol. 10, Issue 1, pp142-151. http://dx.doi.org/10.19045/bspab.2021.100016

\begin{tabular}{llll}
\hline \hline Received: 19/05/2020 & Revised: 05/08/2020 & Accepted: 04/09/2020 & Online First: 17/09/2020 \\
\hline \hline
\end{tabular}

\section{Abstract}

Salinity is increasing problem and is one of the main threats to crop productivity worldwide. Understanding the adverse impact of salt stress $(\mathrm{NaCl})$ at early growth stages is essential for evaluation of salt stress tolerance in plants. A trial was performed during 2017 following completely randomized design (CRD) factorial with three replicates. Three chilli genotypes varieties were received 5 salt stress levels. The canal irigation water having Electrical conductivity (EC) of $0.5 \mathrm{dSm}^{-1}$ was kept as control. The Salinity levels included 1, 3, 5 and 7 $\mathrm{dS} \mathrm{m}^{-1}$, respectively. It was noted that all the studied traits were considerably influenced by salinity $(\mathrm{P}<0.05)$ while chilli genotypes showed similarity $(\mathrm{P}>0.05)$ for germination, leaves plant $^{-1}$ and seedling vigour index and significant $(\mathrm{P}<0.05)$ differences for other traits. The control (non-saline) showed better performance with $84.4 \%$ germination, 5.64 leaves plant $^{-1}$, 905.4 seedling vigour index, $10.7 \mathrm{~cm}$ shoot length, $0.7 \mathrm{~g}$ fresh root biomass weight, $13.3 \mathrm{~cm}$ length of the root, $4.8 \mathrm{~g}$ fresh biomass of the shoot $42.5 \%$ electrolyte leakage. Salinity at 1.0 $\mathrm{dS} \mathrm{m}{ }^{-1}$ revealed a slight reduction in germination (80.5\%) 5.12 leaves plant ${ }^{-1}, 843.2$ seedling vigour index $10.4 \mathrm{~cm}$ shoot length, $0.6 \mathrm{~g}$ fresh root biomass weight $13.0 \mathrm{~cm}$ length of the root, $4.5 \mathrm{~g}$ fresh biomass of the shoot and $48.4 \%$ electrolyte leakage. Further increase in salinity showed simultaneous negative impact on all the observed parameters. There was a negligible difference in studied traits when Sky lane-4 was compared with Ghotki. Overall variety Pusa Jawala was most sensitive to salt stress.

Keywords: Salinity; seed germination; seedling growth; chilli genotypes

\section{Introduction}

Chilli, (Capsicum annum L.) is a member of Solanaceae family grown for its fruit and is popular for its aromatic and pleasant flavor and pungency. The use of chillies is common for culinary purposes, beverage and pharmaceutical industries. There is diverse utility of chilli as spice, culinary supplement, condiment, vegetable and medicine besides its importance as commercial crop. [1]. Salinty is one of the 
main threats to crop productivity globally [2]. Available reports reveal that more than $7 \%$ of the surface of the earth is occupied by salt affected soils and because of salt stress $20 \%$ decrease in yield of cultivated plants has been observed globally [3]. It is well documented that cultivated plants tolerate salt stress to a specifed limit, however, after that threshold level, salt stress significantly induced reduction in yield. The salinity affects plants in different ways, like the first instant impact of salinity for plants is an osmotic effect through which plants loose their internal water balance from their cells [4]. The second hazard of salinity is an ionic effect, where plants face problems of ionic toxicity, especially toxicity of $\mathrm{Na}^{+}$and $\mathrm{Cl}^{-}$ ions [5]. The third negative impact of salinity for plants is the nutrient imbalance, where plants uptake toxic elements like $\mathrm{Na}+$ rather than nutrient elements particularly $\mathrm{K}^{+}$[6]. Plants use several mechanisms to adopt these influences of salinity. Generally, plants synthesize organic acids (proline, glycinebetane, etc) as osmo- protectant the Seed germination is the most vulnerable to salt stress in comparision with other growth stages of plants $[7,8]$. At this stage most vegetable crops exhibit sensitivity even to low concentration of salts to about $75 \mathrm{mM}$ $\mathrm{NaCl}$ [9]. Salinity reduces seed germination percentage and impairs nodule formation and the growth and yield is decreased and survival of plant is jeopardized at later stages. The seed germination is adversely affected by salt stress through osmotic effects and ionic toxicity [10]. The past studies relevant to saline water irrigation showed that the saline water effect is proportional to salinity level and crop species. The seed germination in several crops including chillies is highly sensitive to salinity [11]. While the seedling growth at early stage is also face severe adverse effects of salinity, but some plants species and varieties may have ability to tolerate salinity at this stage [12]. The inhibitory effects of $\mathrm{NaCl}$ on germination are well established [13], it causes reduction in germination rate considerably [14], and consequently caused decline in plant performance in terms of growth, development and yield [15]. The application of phytohormones can mitigate the negative effects of salinity. The concentration of the salts at higher rates reduces the water potential in medium which hinders water acquision and thus reduce seed germination [16]. The speed of germination and the final seed germination percentage determine the ability of the seed to tolerate stresses like salt stress. The rate of seed germination and days taken to seedling emergence in chilli, cabbage, spinach, sugar beet and cauliflower were adversely affected by increasing the salinity levels that salinity considerably affected the $\mathrm{Na}$ content of plant traits including roots, shoots and fruits of pepper and tomato varieties without any effect on crop yields. Evaluating salinity tolerance of plants has been found very successful [17]. Several plant species and varieties have been evaluated and reported as salt-tolerant and sensitive to salinity [18]. To the knowledge of researchers very little information is available on salinity tolerance of condiment plant species, including chillies. In Pakistan chillies are cultivated on large scale however; this crop is facing several problems, including Aflotoxin, waterlogging and salinity. The crop species, cultivars and growing conditions have been documented to affect the response of plants to salinity and associated nutrient acquisition [19]. In the light of above mentioned facts, a pot trial was performed to assess the salt stress tolerance of chilli genotypes at seedling stage.

\section{Materials and Methods}

A pot trial was performed during 2017 following completely randomized design (CRD) factorial with three replicates. Three chilli genotypes viz, Ghotki, Skylane 4 and Pusa Jawala received 5 salt stress levels. Three pots represented each replication; and in each pot seven seeds 
were sown. The earthen pots were filled with a growing medium that included canal sediment, well rooten FYM and garden soil at the ratio of $(1: 1: 1)$. In this research, the seeds of three Chilli genotypes including Ghotki, Skylane 4 and Pusa Jawala were sown in pots. The sodium chloride $(\mathrm{NaCl})$ was used to maintain EC levels in accordance with the treatment levels. Five different $\mathrm{NaCL}$ levels including control (canal water having EC $0.05 \mathrm{dSm}^{-1}$ ) and 1, 3, 5 and 7 $\mathrm{dSm}^{-1}$ were applied. Plants were irrigated with saline water on alternate days and all other cultural operations in the pots were performed manually. After one and half month (45 days), the data were taken for plant traits including leaves plant ${ }^{-1}$, seedling vigour index, shoot length, fresh biomass of shoot, root length, fresh biomass of root and electrolyte leakage of leaf.

\section{Procedures for recording the observations \\ Observations methodology \\ recording \\ Seed germination percentage}

The germination percentage of the seed was done by applying the formula suggested by [20].

$\mathrm{GP}=\Sigma \mathrm{n} / \mathrm{N} \times 100$

Where $\mathrm{n}$ is seeds that were germinated and $\mathrm{N}$ is total seeds that were sown.

\section{Shoot and root related traits}

The measuring scale was used to assess the root and the length of the shoot while fresh root and shoot biomass were measured with electrical balance.

\section{Seedling vigour index}

Seedling Vigor Index (SVI) was measured by using the formula given by [211]

$(\mathrm{SVI})=[$ shoot length $(\mathrm{cm}) \times$ germination percentage]

\section{Electrolyte leakage of leaf}

The leaf Electrolyte leakage \% was assessed by applying the formula given by [22]. The random leaf sample, weighing $0.5 \mathrm{~g}$ was used for measurement of electrolyte leakage. The $25 \mathrm{ml}$ deionized water was used to rinse the leaf samples before incubation for 3 hours at room temperature. The conductivity of the bathing solution was calculated by electrical conductivity (EC) meter after incubation that was considered as (value A). The petal discs were boiled with bathing solution for 15 minutes to lyses all cells. After cooling at room temperature, the conductivity of the bathing solution was again calculated that was considered as (value B). The electrolyte leakage was measured in percent (\%) value by using the following formula.

Electrolyte leakage of leaf $\%=$ (Value A/Value B) x100

\section{Statistical analysis}

The data were analyzed using Statistix-8.1 computer software [23]. The least significant difference (LSD) test at $\mathrm{P} \leq 0.05$ probability level was performed to compare the results and performance of the treatments.

\section{Results and Discussion Germination (\%)}

The data given in (Table 1) indicate the impact of salt stress levels on seed germination of chilli genotypes and comparison was made with control (Canal irrigation water having EC $\left.0.5 \mathrm{dS} \mathrm{m}^{-1}\right)$. The analysis of variance (ANOVA) described significant $(\mathrm{P}<0.05)$ influence of salinity levels on germination. Among salinity levels, chilli genotypes sown in media of $1.0 \mathrm{dS} \mathrm{m}^{-1}$ resulted in maximum germination $(80.5 \%)$ against 84.4 percent germination in control. A decline in germination was recorded with increased salt stress levels. It was noted that with each unit increase in salinity, the germination was adversely affected when compared to control. The genotypes effect showed that chilli genotypes Sky lane-4 and Ghotki resisted to salinity effect with higher germination of 70.5 and $69.5 \%$, respectively; while lowest germination was found in Pusa Jawala (65.2\%). The germination was markedly higher $(86.6 \%)$ in variety Sky lane-4 when treated with with control (canal water). Similarity in germination $(\mathrm{P}>0.05)$ was recorded between control and $1.0 \mathrm{dS} \mathrm{m}^{-1}$ salt stress 
level; while linear decrease in germination with increasing salinity was recorded in rest of the treatments. The highest concentration of $\mathrm{NaCl}$ might have created external osmotic potential by which caused obstacles in acquisition of the optimum quantity of the water for better germination of the seed [24]. These findings are also endorsed by [25], who also got the same results on pepper plants.

Table 1. Mean germination (\%) of chilli genotypes under the influence of different salinity levels

\begin{tabular}{|c|c|c|c|c|}
\hline \multirow{2}{*}{ Salinity levels } & \multicolumn{3}{|c|}{ Chilli Genotypes } & \multirow{2}{*}{ Mean } \\
\hline & $V_{1}=$ Ghotki & $V_{2}=$ Sky lane 4 & $\mathrm{~V}_{3}=$ Pusa Jawala & \\
\hline $\mathbf{S}_{1}=$ Control & 85 & 86.6 & 81.6 & 84.4 A \\
\hline$S_{2}=1.0 \mathrm{dS} \mathrm{m}^{-1}$ & 80 & 81.7 & 80.0 & $80.5 \mathrm{~A}$ \\
\hline$S_{3}=3.0 \mathrm{dS} \mathrm{m}^{-1}$ & 70 & 72.3 & 65.0 & 69.1 B \\
\hline$S_{4}=5.0 \mathrm{dS} \mathrm{m}^{-1}$ & 58.3 & 61.6 & 55.1 & $58.3 \mathrm{C}$ \\
\hline$S_{5}=7.0 \mathrm{dS} \mathrm{m}^{-1}$ & 54.3 & 50.1 & 44.6 & 49.7 D \\
\hline Mean & $69.5 \mathrm{AB}$ & $70.5 \mathrm{~A}$ & $65.2 \mathrm{~B}$ & - \\
\hline
\end{tabular}

S.E. 2.979, LSD 0.05; 6.103

\section{Leaves plant ${ }^{-1}$}

The results shown in (Table 2) imitate the impact of varying salt stress levels on leaves plant ${ }^{-1}$ of three chilli genotypes as compared to control. The ANOVA suggested that the effect of salinity on leaves plant $^{-1}$ was significant $(\mathrm{P}<0.05)$, while genotypes did not vary significantly in leaves plant. It was noted that among salinity levels, chillies sown in media of $1.0 \mathrm{dS} \mathrm{m}^{-1}$ produced more leaves (5.1) plant $^{-1}$ against 5.6 leaves plant ${ }^{-1}$ in control. A marked decrease in leaves plant ${ }^{-1}$ was noted with increasing salinity levels upto $3.0 \mathrm{dS} \mathrm{m} \mathrm{m}^{-1}$ (4.5), $5.0 \mathrm{dS} \mathrm{m}^{-1}$ (3.6) and lowest 3.31 were observed under highest salt stress. The increase in salinity proportionately caused a decrease in the leaves plant ${ }^{-1}$ over control. The genotypes effect indicates that chilli cultivars Sky lane- 4 and Ghotki gave relatively more leaves plant $^{-1}$ of 4.5 and 4.4, respectively; while minimum leaves plant $^{-1}$ were found in variety Pusa Jawala (4.2). The treatment interaction indicates that leaves plant $^{-1}$ were markedly highest (5.3) in Sky lane-4 at salt stress of $1.0 \mathrm{dS} \mathrm{m}^{-1}$; while minimum leaves plant ${ }^{-1}$ of 3.2 were recorded in Pusa Jawala $\times 7.0 \mathrm{dS} \mathrm{m}^{-1}$ salt stress. There was adverse influence of increased salinity and a simultaneous decrease in leaves number was recorded with each increased salinity level. This reflected that highest salt concentration caused ion toxicity of sodium and chloride in plants that might have adversely affected plant metabolic process These findings have been endorsed by who showed that there was a negative impact of salt stress on pepper plants. The parameters, root length, number and size of leaves reduced considerably under high salt concentration. [26], evaluated salinity tolerance of plants by hydroponics approach and reported that all parameters related to foliage were adversly affected by increased salinity levels.

\section{Seedling vigour index}

The data shown in (Table 3), reflects the impact of salinity levels on seedling vigour index of chilli genotypes over control. The ANOVA revealed that the effect of salinity on seedling vigour index was significant $(\mathrm{P}<0.05)$, while genotypes did not vary significantly in seedling vigour index. It was noted that among salinity levels, seedling vigour index was maximum (843.2) in chillies sown in media of $1.0 \mathrm{dS}$ $\mathrm{m}^{-1}$ against 905.4 seedling vigour index in control. The seedling vigour index decreased considerably to 617.7 and 426.5 when the genotypes were sown in media of 3.0 and $5.0 \mathrm{dS} \mathrm{m}^{-1}$, respectively. [27]. The increase in salinity inversely influenced the seedling vigour index. The varietal 
effect indicates that seedling vigour index was higher in Sky lane-4 (678.7) and Ghotki (628.5), respectively; while minimum seedling vigour index were found in Pusa Jawala (563.5). The treatment interaction showed that seedling vigour index was considerably highest (894.5) in Sky lane-4 at salt stress of 1.0 $\mathrm{dS} \mathrm{m}{ }^{-1}$; while lowest seedling vigour index of 265.5 was determined in interaction of genotype Pusa Jawala $\times 7.0 \mathrm{dS} \mathrm{m}^{-1}$ salinity level. Similarity $(\mathrm{P}>0.05)$ was determined in seedling vigour index between control and $1.0 \mathrm{dS} \mathrm{m}^{-1}$. The seedling vigour index was adversely affected by increasing salinity level but this effect was not variety specific and all the varieties showed almost similar response to salinity levels.

Table 2. Mean number of leaves plant ${ }^{-1}$ of chilli genotypes under the influence of different salinity levels

\begin{tabular}{|c|c|c|c|c|}
\hline \multirow{2}{*}{ Salinity levels } & \multicolumn{3}{|c|}{ Chilli genotypes } & \multirow{2}{*}{ Mean } \\
\hline & $V_{1}=$ Ghotki & $V_{2}=$ Sky lane 4 & $V_{3}=$ Pusa Jawala & \\
\hline$S_{1}=$ Control & 5.9 & 5.7 & 5.2 & $5.6 \mathrm{~A}$ \\
\hline$S_{2}=1.0 \mathrm{dS} \mathrm{m}^{-1}$ & 5.1 & 5.3 & 4.9 & $5.1 \mathrm{~A}$ \\
\hline$S_{3}=3.0 \mathrm{dS} \mathrm{m}^{-1}$ & 4.5 & 4.5 & 4.4 & $4.5 \mathrm{~B}$ \\
\hline$S_{4}=5.0 \mathrm{dS} \mathrm{m}^{-1}$ & 3.5 & 3.8 & 3.4 & $3.6 \mathrm{C}$ \\
\hline$S_{5}=7.0 \mathrm{dS} \mathrm{m}^{-1}$ & 3.3 & 3.4 & 3.2 & $3.3 \mathrm{C}$ \\
\hline Mean & 4.4 & 4.5 & 4.2 & - \\
\hline
\end{tabular}

S.E. 0.315 , LSD $0.05 ; 0.646$

Table 3. Mean seedling vigour index of chilli genotypes under the influence of different salinity levels

\begin{tabular}{|c|c|c|c|c|}
\hline \multirow{2}{*}{ Salinity levels } & \multicolumn{3}{|c|}{ Chilli genotypes } & \multirow{2}{*}{ Mean } \\
\hline & $V_{1}=$ Ghotki & $V_{2}=$ Sky lane 4 & $V_{3}=$ Pusa Jawala & \\
\hline $\mathbf{S}_{1}=$ Control & 893 & 1019.0 & 803.6 & $905.4 \mathrm{~A}$ \\
\hline$S_{2}=1.0 \mathrm{dS} \mathrm{m}^{-1}$ & 831 & 894.5 & 804.0 & 843.2 A \\
\hline$S_{3}=3.0 \mathrm{dS} \mathrm{m}^{-1}$ & 635 & 656.7 & 560.6 & 617.7 B \\
\hline$S_{4}=5.0 \mathrm{dS} \mathrm{m}^{-1}$ & 416 & 479.2 & 384.0 & $426.5 \mathrm{C}$ \\
\hline$S_{5}=7.0 \mathrm{dS} \mathrm{m}^{-1}$ & 365 & 344.3 & 265.5 & 325.0 D \\
\hline Mean & 628.5 & 678.7 & 563.5 & - \\
\hline
\end{tabular}

S.E. 45.79, LSD 0.05; 93.810

\section{Shoot length (cm)}

The results given in (Table 4), reveal salinity impact on length of the shoot of different chilli genotypes in comparison with control. The ANOVA demonstrated that the increase in salinity had adverse impact on length of the shoot; and chilli genotypes also responded differently to salinity for length of the shoot. It is obvious from the results that among treatments, genotypes sown in media of $1.0 \mathrm{dS} \mathrm{m}^{-1}$ revealed maximum length of shoot $(10.4 \mathrm{~cm})$ against $10.7 \mathrm{~cm}$ shoot length under control. The lowest shoot length of $6.5 \mathrm{~cm}$ was recorded at salt stress of $7.0 \mathrm{dS} \mathrm{m}{ }^{-1}$. The varietal effect indicates that shoot length was higher in Sky lane-4 $(9.2 \mathrm{~cm})$ and Ghotki (8.7), respectively; while Pusa Jawala showed least shoot length $(8.3 \mathrm{~cm})$. The treatment interaction indicates that shoot length was much higher $(10.9 \mathrm{~cm})$ in Sky lane-4 $\times 1.0 \mathrm{dS} \mathrm{m}^{-}$ ${ }^{1}$ at salinity level; while minimum shoot length of $5.9 \mathrm{~cm}$ was noted in interaction of Pusa Jawala $\times 7.0 \mathrm{dS} \mathrm{m} \mathrm{m}^{-1}$. Similarity $(\mathrm{P}>0.05)$ was observed in shoot length between control and $1.0 \mathrm{dS} \mathrm{m}{ }^{-1}$ salinity level. The length of the shoot was adversely affected by increasing salinity level as well as genotypes also responded differently to salinity levels, in salinity influenced significantly shoots and roots of 
the plants for their size and fresh weight. [28]. has reported that because of toxicity of ions $\left(\mathrm{Na}^{+}\right.$and $\mathrm{Cl}^{-}$ions) caused by salt stress, the plant performance in terms of growth, and yield reduced significantly. Moreover, this also led to soil and plant osmotic imbalances.

Table 4. Mean shoot length $(\mathrm{cm})$ of chilli genotypes under the influence of different salinity levels

\begin{tabular}{|c|c|c|c|c|}
\hline \multirow{2}{*}{ Salinity levels } & \multicolumn{3}{|c|}{ Chilli genotypes } & \multirow{2}{*}{ Mean } \\
\hline & $V_{1}=$ Ghotki & $V_{2}=$ Sky lane 4 & $V_{3}=$ Pusa Jawala & \\
\hline $\mathbf{S}_{1}=$ Control & 10.5 & 11.7 & 10.0 & $10.7 \mathrm{~A}$ \\
\hline$S_{2}=1.0 \mathrm{dS} \mathrm{m}^{-1}$ & 10.3 & 10.9 & 10.0 & $10.4 \mathrm{~A}$ \\
\hline$S_{3}=3.0 \mathrm{dS} \mathrm{m}^{-1}$ & 9.0 & 9.1 & 8.7 & $8.9 \mathrm{~B}$ \\
\hline$S_{4}=5.0 \mathrm{dS} \mathrm{m}^{-1}$ & 7.2 & 7.8 & 6.9 & $7.3 \mathrm{C}$ \\
\hline$S_{5}=7.0 \mathrm{dS} \mathrm{m}^{-1}$ & 6.7 & 6.8 & 5.9 & $6.5 \mathrm{C}$ \\
\hline Mean & $8.7 \mathrm{AB}$ & $9.2 \mathrm{~A}$ & $8.32 \mathrm{~B}$ & - \\
\hline
\end{tabular}

S.E. 0.606, LSD $0.05 ; 1.242$

\section{Fresh shoot biomass (g)}

The data shown in (Table 5), indicated the salinity impact on fresh shoot biomass of different genotypes of chilli over control. The ANOVA demonstrated that salt stress showed highly negative impact on fresh shoot biomass. The genotypes also differed in fresh shoot biomass considerably. The data show that among treatments (salinity levels), genotypes sown in media of $1.0 \mathrm{dS} \mathrm{m}^{-1}$ showed highest shoot biomass (4.5g) against $4.8 \mathrm{~g}$ fresh shoot biomass in control. The fresh shoot biomass reduced to $3.3 \mathrm{~g}$ and $2.2 \mathrm{~g}$ when the genotypes were sown in media of 3.0 and $5.0 \mathrm{dS} \mathrm{m} \mathrm{m}^{-1}$, respectively. The lowest values pertaining to fresh shoot biomass was determined under highest salt stress level. In genotypes, the fresh shoot biomass was higher in chilli genotypes Sky lane-4 while Pusa Jawala showed minimum fresh shoot biomass. In the present investigation the reduced shoot biomass under higher salinity level might be due to the negative influence of NaCL on growth of shoot. This also reflects that less fresh biomass under high salt stress might have been associated with dcreased acquisition of water by plants at early stage [29], also found that seedling height, leaves and branching, fresh and dry biomass of shoots and roots were declined under salt stress.

\section{Root length $(\mathrm{cm})$}

The data given in (Table 6), represent the salinity effect on root length of various chilli genotypes over control. The ANOVA displayed that the varied salinity levels had negative impact on root length; and chilli genotypes also differed significantly for root length at various salt stress levels. The plants grown under the influence of canal water produced longer roots $(13.3 \mathrm{~cm})$. The root length declined to $11.4 \mathrm{~cm}$ and $9.2 \mathrm{~cm}$ when the chillies were sown in media of 3.0 and $5.0 \mathrm{dS} \mathrm{m}^{-1}$, respectively; while the lowest root length $(8.1 \mathrm{~cm})$ was recorded under highest salt stress level. The root length was negatively influenced by increased salinity level; and varieties also had significant difference for this trait under various salinity levels. Among genotypes, the root length was higher in chilli cultivars Sky lane-4 (11.3 $\mathrm{cm})$ as compared to Ghotki $(11.1 \mathrm{~cm})$; while Pusa Jawala showed least root length $(10.7 \mathrm{~cm})$. The salt stress levels of $1 \mathrm{dSm}^{-1}$ and control showed nonsignificant $(\mathrm{P}>0.05)$ response for root length. Root length is one of the important parameters that largely determines the success of the plants under diverse environmental conditions especially salt stress growth conditions. In the present investigation the highest salt concentration showed poor growth of the roots largely 
due to ion toxicity if $\mathrm{Na}$ and chloride salts. This might have created hinderances in normal metabolic processes of plants consequently plants with poor growth of the roots were produced. [30], have also described the highly adverse effect of salinity on canola cultivars.

Table 5. Mean fresh root biomass (g) of chilli genotypes under the influence of different salinity levels

\begin{tabular}{|c|c|c|c|c|}
\hline \multirow{2}{*}{ Salinity levels } & \multicolumn{3}{|c|}{ Chilli genotypes } & \multirow{2}{*}{ Mean } \\
\hline & $V_{1}=$ Ghotki & $V_{2}=$ Sky lane 4 & $\mathrm{~V}_{3}=$ Pusa Jawala & \\
\hline$S_{1}=$ Control & 0.7 & 0.7 & 0.6 & $0.7 \mathrm{~A}$ \\
\hline$S_{2}=1.0 \mathrm{dS} \mathrm{m}^{-1}$ & 0.6 & 0.7 & 0.6 & $0.6 \mathrm{~A}$ \\
\hline$S_{3}=3.0 \mathrm{dS} \mathrm{m}^{-1}$ & 0.5 & 0.6 & 0.5 & $0.5 \mathrm{~B}$ \\
\hline$S_{4}=5.0 \mathrm{dS} \mathrm{m}^{-1}$ & 0.5 & 0.5 & 0.4 & $0.4 \mathrm{C}$ \\
\hline$S_{5}=7.0 \mathrm{dS} \mathrm{m}^{-1}$ & 0.4 & 0.4 & 0.3 & $0.4 \mathrm{D}$ \\
\hline Mean & $0.5 \mathrm{~B}$ & $0.6 \mathrm{~A}$ & $0.5 \mathrm{C}$ & - \\
\hline
\end{tabular}

S.E. 0.024, LSD 0.05; 0.049

Table 6. Mean root length $(\mathrm{cm})$ of chilli genotypes under the influence of different salinity levels

\begin{tabular}{|c|c|c|c|c|}
\hline \multirow{2}{*}{ Salinity levels } & \multicolumn{3}{|c|}{ Chilli genotypes } & \multirow{2}{*}{ Mean } \\
\hline & $V_{1}=$ Ghotki & $V_{2}=$ Sky lane 4 & $\mathrm{~V}_{3}=$ Pusa Jawala & \\
\hline $\mathbf{S}_{1}=\mathbf{C o n t r o l}$ & 13.3 & 13.8 & 12.9 & $13.3 \mathrm{~A}$ \\
\hline$S_{2}=1.0 \mathrm{dS} \mathrm{m}^{-1}$ & 13.2 & 13.4 & 12.4 & $13.0 \mathrm{~A}$ \\
\hline$S_{3}=3.0 \mathrm{dS} \mathrm{m}^{-1}$ & 11.4 & 11.7 & 11.2 & $11.4 \mathrm{~B}$ \\
\hline$S_{4}=5.0 \mathrm{dS} \mathrm{m}^{-1}$ & 9.2 & 9.4 & 9.0 & $9.2 \mathrm{C}$ \\
\hline$S_{5}=7.0 \mathrm{dS} \mathrm{m}^{-1}$ & 8.2 & 8.3 & 7.9 & $8.1 \mathrm{D}$ \\
\hline Mean & 11.1 B & $11.3 \mathrm{~A}$ & $10.7 \mathrm{C}$ & - \\
\hline
\end{tabular}

S.E. 0.155 , LSD $0.05 ; 0.317$

\section{Fresh root biomass (g)}

The data shown in (Table 7), disclose the salinity influence on fresh root biomass of various genotypes of chilli as compared to control. The ANOVA exhibited that the increasing salt stress had detrimental effect on fresh root biomass; and chilli genotypes also showed significantly different response to salinity levels for fresh root biomass. The results indicated that among treatments (salinity levels), genotypes sown in media of $1.0 \mathrm{dS} \mathrm{m} \mathrm{m}^{-1}$ showed maximum root biomass ( $0.6 \mathrm{~g})$ against 0.7 $\mathrm{g}$ fresh root biomass in control. The fresh root biomass decreased to $0.5 \mathrm{~g}$ and $0.4 \mathrm{~g}$ when the salt stress levels increased to 3.0 and $5.0 \mathrm{dS} \quad \mathrm{m}^{-1}$, respectively. The minimum fresh root biomass $(0.4 \mathrm{~g})$ was recorded under highest salt stress of 7 $\mathrm{dSm}^{-1}$. The fresh root biomass was adversely influenced by increasing salinity level and genotypes also responded differently to salinity. Among varieties, the fresh root biomass was higher in chilli cultivars Sky lane-4 (0.6 g) as compared to Ghotki (0.5); while Pusa Jawala showed lowest root biomass. For root biomass, the differences were not-significant between control and $1.0 \mathrm{dS} \mathrm{m} \mathrm{m}^{-1}$. These results refelected that plant mechanism regarding to salt stress is not well developed at early stages of chilli plants [31]. It has been well documented that salt stress causes adverse effect on uptake of vital nutrients elements such as phosphorus $(\mathrm{P})$ and potassium $(\mathrm{K})$ that could lead to poor growth of young seedlings [32].

\section{Electrolyte leakage of leaf $(\%)$}

The Data in regards to electrolyte leakage in different genotypes of chilli as affected by salinity levels are given in (Table 8). The ANOVA revealed that the electrolyte 
leakage was considerably influenced by various salt stress levels in different genotypes. The maximum electrolyte leakage $(79.1 \%)$ was determined in genotypes grown at highest salt stress of $7.0 \mathrm{dS} \mathrm{m} \mathrm{m}^{-1}$. The electrolyte leakage decreased to 67.0 and $57.9 \%$ when the genotypes were sown in media of 5.0 and $3.0 \mathrm{dS} \mathrm{m} \mathrm{m}^{-1}$, respectively. The lowest electrolyte leakage (42.5\%) among treatments was determined in control. The electrolyte leakage increased considerably with each increment in salinity level. In varieties, the electrolyte leakage was greater in genotype Pusa Jawala (60.9\%) as compared to Ghotki (59.2\%); while the lowest electrolyte leakage $(56.5 \%)$ was recorded in variety Sky lane-4. The treatment interaction indicates that electrolyte leakage was much higher (83.6) in Pusa Jawala $\times 7.0 \mathrm{dS} \mathrm{m}^{-1}$; while minimum electrolyte leakage of $40.8 \%$ was determined in interaction of Sky lane$4 \times 1.0 \mathrm{dS} \mathrm{m} \mathrm{m}^{-1}$. The differences were insignificant statistically $(\mathrm{P}>0.05)$ in electrolyte leakage between Pusa Jawala and Ghotki. In the current study, the highest electrolyte leakage of the leaf at elevated salinity was possibly due to the inability of the leaf to reorganize cellular membranes promptly and efficiently. Moreover, plants failed to avoid dehydration of water that showed more electrolyte leakage of leaf in the water [33, 34], mentioned that increasing salinity level not only adversely affects the agronomical performance of the crop, but the physiological aspects are also influenced simultaneously in negative direction.

Table 7. Mean fresh shoot biomass (g) of chilli genotypes as under the influence of different salinity levels

\begin{tabular}{|c|c|c|c|c|}
\hline \multirow{2}{*}{ Salinity levels } & \multicolumn{3}{|c|}{ Chilli genotypes } & \multirow{2}{*}{ Mean } \\
\hline & $V_{1}=$ Ghotki & $V_{2}=$ Sky lane 4 & $V_{3}=$ Pusa Jawala & \\
\hline $\mathrm{S}_{1}=$ Control & 4.6 & 5.3 & 4.5 & $4.8 \mathrm{~A}$ \\
\hline$S_{2}=1.0 \mathrm{dS} \mathrm{m}^{-1}$ & 4.3 & 4.9 & 4.3 & $4.5 \mathrm{~A}$ \\
\hline$S_{3}=3.0 \mathrm{dS} \mathrm{m}^{-1}$ & 3.3 & 3.4 & 3.2 & $3.3 \mathrm{~B}$ \\
\hline$S_{4}=5.0 \mathrm{dS} \mathrm{m}^{-1}$ & 2.2 & 2.5 & 2.1 & $2.2 \mathrm{C}$ \\
\hline$S_{5}=7.0 \mathrm{dS} \mathrm{m}^{-1}$ & 1.4 & 1.5 & 1.3 & $1.4 \mathrm{D}$ \\
\hline Mean & $3.2 \mathrm{~B}$ & $3.5 \mathrm{~A}$ & $3.0 \mathrm{~B}$ & - \\
\hline
\end{tabular}

S.E. 0.235 , LSD $0.05 ; 0.481$

Table 8. Mean electrolyte leakage (\%) of chilli genotypes under the influence of different salinity levels

\begin{tabular}{|c|c|c|c|c|}
\hline \multirow{2}{*}{ Salinity levels } & \multicolumn{3}{|c|}{ Chilli genotypes } & \multirow{2}{*}{ Mean } \\
\hline & $V_{1}=$ Ghotki & $\mathrm{V}_{2}=$ Sky lane 4 & $\mathrm{~V}_{3}=$ Pusa Jawala & \\
\hline $\mathrm{S}_{1}=$ Control & 42.3 & 40.8 & 44.6 & $42.5 \mathrm{E}$ \\
\hline$S_{2}=1.0 \mathrm{dS} \mathrm{m}^{-1}$ & 47.7 & 46.8 & 50.7 & 48.4 D \\
\hline $\mathrm{S}_{3}=3.0 \mathrm{dS} \mathrm{m}^{-1}$ & 58.2 & 54.0 & 61.4 & $57.9 \mathrm{C}$ \\
\hline$S_{4}=5.0 \mathrm{dS} \mathrm{m}^{-1}$ & 69.6 & 67.2 & 64.3 & $67.0 \mathrm{~B}$ \\
\hline$S_{5}=7.0 \mathrm{dS} \mathrm{m}^{-1}$ & 78.2 & 75.6 & 83.6 & $79.1 \mathrm{~A}$ \\
\hline Mean & $59.2 \mathrm{~A}$ & $56.5 \mathrm{~B}$ & $60.9 \mathrm{~A}$ & - \\
\hline
\end{tabular}

S.E. 1.418, LSD 0.05; 2.905

\section{Conclusion}

It was concluded that increase in salinity showed severe adverse effects on the seed germination and early seedling growth of chilli genotypes. The effect on germination and seedling growth was negligible upto $1.0 \mathrm{dS} \mathrm{m} \mathrm{m}^{-1}$ salinity. Moreover, the threshold level for chilliies was recorded $1.0 \mathrm{dS} \mathrm{m}^{-1}$ in the current study. The increasing salt stress beyond this level 
showed severe adverse effect on germination and seedling growth. Among chilli varieties, Sky lane 4 and Ghotki showed tolerance to salinity; while Pusa Jawala did not prove its tolerance to salinity.

\section{Authors' contributions}

Concieved and designed the experiments: NA Wahocho \& A Qadir, Performed the experiments: H Latif, NN Memon, QB Baloch \& AN Shah. Analysis the data: ZA Abbasi \& NA Wahocho, Contributed materials/ analysis/tools: S Keerio, NA Wahocho, H Latif, SA Wahocho, Jakhro MI \& Abro JA. Wrote the paper: NA Wahocho \& A Qadir.

\section{References}

1. Almodares A, Hadi MR \& Dosti B (2007). Effects of salt stress on germination percentage and seedling growth in sweet sorghum cultivars. $J$ of Biological Sci 7(8): 1492-1495.

2. Anantharaju P \& Muthiah AR (2007). Effect of Nacl salinity stress on seed germination and seedling growth of chick pea (Cicer arietinum L.). Legume Res 30(2): 141-144.

3. Ahmed OA, Unlukara A, Ipek G \& Bilal (2004). Effects of salt stress and water deficit on plant growth and essential oil content of lemon balm (Melissa officinalis L.). Pak J Bot 36(4): 787-792.

4. Ahn TI \& Son JE (2011). Changes in ion balance and individual ionic contributions to EC reading at different renewal intervals of nutrient solution under ECbased nutrient control in closed-loop soilless culture for sweet peppers (Capsicum annuum L. 'Fiesta'). Kor J Hort Sci Technol 29(3): 29-35.

5. Ali Y, Aslam Z, Ashraf MY \& Tahir GR (2007). Effect of salinity on chlorophyll concentration, leaf area, yield and yield components of rice genotypes grown under saline environment. Int J Env Sci Tech 1(3): 221-225.

6. Baiyeri KP \& Mbah BN (2006). Effects of soilless and soil based nursery media on seedling emergence, growth and response to water stress of African breadfruit (Treculia Africana Decne). African J Biotech 5(30): 1405-1410.
7. Bein EB, Habte A, Jaber A, Birnie A \& Tengnas B (2014). Useful trees and shrubs in Eriteria, identification, propagation and management for Agricultural Pastoral Communities, Technical Hand Book No. 12, SIDA, Regional Soil Conservation Unit, Nairobi.

8. Bybordi A, Tabatabaei SJ \& Ahmedov A (2010) Effect of salinity on the growth and peroxidase and IAA oxidase activities in canola. $J$ of Food, Agric and Environ 8(1): 109-112.

9. Cony MA \& Trione SO (1998). Inter- and intraspecific variability in Prosopis flexuosa and $P$. chilensis: seed germination under salt and moisture stress. J of Arid Environ 40(2): 307-317.

10. Daei G, Ardekani MR, Rejali F, Teimuri S \& Miransari M (2009). Alleviation of salinity stress on wheat yield, yield components, and nutrient uptake using arbuscular mycorrhizal fungi under field conditions. J Plant Physiol 16(6): 617625.

11. Evelin H, Kapoor R \& Giri B (2009). Arbuscular mycorrhizal fungi in alleviation of salt stress: A review Ann Bot 10(4): 1263-1280.

12. Foolad MR (2004). Recent advances in genetics of salt tolerance in tomato. Plant Cell Tissue and Organ Culture 7(6): 101119.

13. Hassen A, Maher S \& Chrif H (2013). Effect of Salt Stress $(\mathrm{NaCl})$ on Germination and Early Seedling Parameters of Three Pepper Cultivars (Capsicum annuum L.). J Stress Physi \& Biochem 24(2): 326-167.

14. Jamil MD, Baelee KY, Jung M, Ashraf S, Lee C \& Rha ES (2006). Effect of salt $(\mathrm{NaCl})$ stress on germination and early seeding growth of four vegetables species. J Cent Euro Agric 7(2): 273-282.

15. Jones RL (2004). Effect of growing media on seed germination and seedling growth of chillies cv. Red lady. African J of Plant Sci 8(4): 178-184.

16. Karajol, K \& Naik GR (2011). Seed Germination Rate as a Phenotypical Marker for the Selection of $\mathrm{NaCl}$ Tolerant Cultivars in Pigeon Pea (Cajanuscajan L. Millsp.) World J of Sci and Technol 1(2): $2231-2587$. 
17. Kaveh M (2011). Chilli: The most valuable cash crop. The Financial Daily, Saturday $17^{\text {th }}$ April, 2011.

18. Kodalli SH (2006). Studies on integrated nutrient management on seed yield and quality of chilli. M.Sc. Thesis submitted to the University of Agricultural Sciences, Dharwad, Kranatka, India.

19. Liopa TA, Kaspiris G, Salahas G \& Barouchas P (2012). Effect of salicylic acid (SA) and gibberellic acid (GA3) presoaking on seed germination of stevia (Stevia rebaudiana) under salt stress. J of Medicinal Plants Res 6(1): 416-423.

20. Larsen SU \& Andreasen C (2004). Light and heavy turf-grass seeds differ in germination percentage and mean germination thermal time. Crop Sci. 4(4): 1710-1720.

21. Maheswari TU, Haripriya K \& Kamalakannan S (2013). Impact of foliar organic nutrients on nutrient uptake pattern of chilli Capsicum annuum L. cv. K2. South Indian Hort 51(1/6): 168-172.

22. Munns R \& Tester M (2008). Mechanism of salinity tolerance. Ann Rev Plant Biol 5(9): 651-681.

23. Malawadi MN, Shashidhara GB \& Palled YB (2015). Effect of secondary and micronutrients on yield, nutrient uptake and quality of chilli. Karnataka J Agri Sci 17(3): 553-556.

24. Mohammed B, Jean-Marie K \& Stanley L (2001). The use of the electrolyte leakage method for assessing cell membrane stability as a water stress tolerance test in durum wheat. Plant Growth Reg 21(4): $1-10$.

25. Nasri N, Mahmoudi H, Baatour O, M'rah S, Kaddour R \& Lachâal M. (2012). Effect of exogenous gibberellic acid on germination, seedling growth and phosphatase activities in Lettuce under salt stress. African J of Biotechnol 1(1): 11967-11971.

26. Nzanza NR, Suleiman MK, Al-Menaie H, Al-Ali EH, Al-Mulla L, Al-Zalzaleh M \&
Bellen R (2012). Use of hydrophilic polymers and mulches for water conservation in greenery projects in Kuwait. Kuwait Institute for Scientific Research, Report No. KISR 8034 Kuwait.

27. Nasim M, Qureshi R, Aziz T, Saqib M, Nawaz S, Sahi ST \& Pervaiz S (2008). Growth and ionic composition of salt stressed Eucalyptus camaldulensis and Eucalyptus teretcornis. Pak J of Bot 40(20: 799-805.

28. Porcel R, Aroca R \& Ruiz-Lozano JM (2012). Salinity stress alleviation using arbuscular mycorrhizal fungi. A review. Agron Sustain Dev 3(2): 181-200.

29. Qadir J, Gorham J \& Qureshi RH (2007). Combine effect of salinity and hypoxia in wheat (Triticum aestivum L.) and wheatThynopyrum amphiploids. Plant Soil 16(6): 47-54.

30. Shahba $\mathrm{T}$, Souguir $\mathrm{M} \&$ Hannachi $\mathrm{C}$ (2014). Effect of Salt Stress $(\mathrm{NaCl})$ on Germination and Early Seedling Parameters of Three Pepper Cultivars (Capsicum annuum L.). J of Stress Physiol \& Biochem 10(1): 14-25.

31. Sharma BR, Chadha APS \& Bajpai HK (2014). Response of chilli Capsicum annuum Linn. to nitrogen and phosphorus levels under irrigated condition. $A d v$ in $P l$ Sci 9(2): 213-214.

32. Statistix, 2006. Analytical Software. Statistix 8.1 User's Manual. Analytical Software, Tallahssee, Florida.

33. Undersander M, Wattchara T, Amorn T \& Phimoon A (2009). Evaluation of an onfarm organic growing media on the growth and development of pepper seedlings. As J Food Ag-Ind 2(1): 75-80.

34. Zhani K, Mariem BF, Fardaous M \& Cherif H (2014). Impact of salt stress $(\mathrm{NaCl})$ on growth, chlorophyll content and fluorescence of Tunisian cultivars of chili pepper (Capsicum frutescens L.). J of Stress Physiol \& Biochem 8(4): 236-252. 